\title{
Weight and Body Composition Changes during the First Three Years of College
}

\author{
Sareen S. Gropper, ${ }^{1}$ Karla P. Simmons, ${ }^{2}$ Lenda Jo Connell, ${ }^{2}$ and Pamela V. Ulrich² \\ ${ }^{1}$ Department of Nutrition, Dietetics, and Hospitality Management, Auburn University, 101 Poultry Science Building, AL 36849, USA \\ ${ }^{2}$ Department of Consumer Affairs, Auburn University, 308 Spidle Hall, AL 36849, USA
}

Correspondence should be addressed to Sareen S. Gropper, groppss@auburn.edu

Received 19 April 2012; Accepted 26 August 2012

Academic Editor: Francesco Saverio Papadia

Copyright (C) 2012 Sareen S. Gropper et al. This is an open access article distributed under the Creative Commons Attribution License, which permits unrestricted use, distribution, and reproduction in any medium, provided the original work is properly cited.

\begin{abstract}
Differences in weight, body mass index (BMI), percent and absolute body fat, fat-free mass, and waist circumference were investigated in a group of males and females during the first three years (from 2007 to 2010) of college. Significant three-year gains were observed for weight $2.1 \pm 4.7 \mathrm{~kg}$, BMI $0.7 \pm 1.6 \mathrm{~kg} / \mathrm{m}^{2}$, percent body fat $2.7 \pm 3.3 \%$, and fat mass $2.3 \pm 3.5 \mathrm{~kg}$. A significant loss of fat-free mass, $-0.5 \mathrm{~kg}$, was observed among females. Absolute gains in weight, BMI, and percent and absolute body fat were highest during the freshman year, followed by the junior year, and lowest during the sophomore year. Among the $70 \%$ of students gaining weight over the three years, weight gain averaged $4.3 \mathrm{~kg}$. The numbers of females with over $30 \%$ body fat doubled, and the number of males with over $20 \%$ body fat increased fivefold. Initially $15 \%$ of students were classified as obese/overweight and $79 \%$ normal weight; by the end of the junior year, $24 \%$ were obese/overweight and $70 \%$ were normal weight. Efforts on college campuses to promote healthy lifestyles among its student population are needed throughout the college years.
\end{abstract}

\section{Introduction}

None of the 50 states met the nation's Healthy People 2010 goal to lower the prevalence of obesity to $15 \%$; further, in 2010, the number of states with an obesity prevalence of $30 \%$ or more increased from nine to 12 [1]. The problem of overweight and obesity in the state of Alabama is of considerable magnitude, given the state is ranked as the second most obese state in the nation with $33 \%$ of residents classified as obese [2]. Moreover, in Alabama's young adult age group (from 18 to 24 years), almost half, $48.1 \%$, are overweight or obese [2]. Nationally, it is the young adult group (ages 18 to 29 years) that has experienced the greatest increases in overweight and obesity [3].

Weight gain has been extensively studied among young adults in college, especially during the freshman year. While these studies have clearly shown that the "freshman 15," the common belief that students gain 15 pounds $(6.8 \mathrm{~kg})$ during the freshman year of college, is a myth, average weight gains of 3 to $5 \mathrm{lbs}$ ( 1.4 to $2.3 \mathrm{~kg}$ ) during the first year of college have been documented [4-25]. A few studies assessing changes into the sophomore year showed that weight and body mass index gains continue but at a decreased rate versus the freshman year $[10,15,26-28]$. Total gains of about $1.8 \mathrm{~kg}$ ( $4 \mathrm{lbs}$ ) by the end of their second year in college, and when only those who gained weight were considered, weight gains of about $4.1 \mathrm{~kg}$ (9lbs) have been reported [10,27]. These weight gains, however, were found to be accompanied by healthier changes in body composition, specifically lower gains in body fat and greater gains or less loss of fat-free mass during the sophomore year than the freshman year [10]. Yet, in addition to these findings, increases in the percentages of students classified as overweight and with unhealthy body fat amounts and waist circumferences also have been observed during the sophomore year $[10,26]$. If such changes continue throughout and beyond the college years, the risk of several health problems including cardiovascular disease, type 2 diabetes, arthritis, impaired mobility, and some cancers may rise [29]. Given that the greatest increases in obesity prevalence have been observed in this young, adult, primarily college-aged, group, further characterization of changes that occur during the later years of college is needed. The purpose 
of the present study was to extend the findings of previous studies, examining changes in body weight and BMI, but also to add to the literature reported changes in body composition (including percent and absolute fat mass, and fat-free mass) and waist circumference in a group of male and female students during the first three years of college.

\section{Participants and Methods}

Freshmen were recruited from Auburn University's incoming freshman class via email, fliers, and class announcements in introductory level courses typically taken by first year students at the beginning of fall semester 2007. Auburn University's 2007 incoming freshman class consisted of 4,191 students and was $53 \%$ female and $47 \%$ male. This freshman class was mostly Caucasian (81.7\%), followed by African American (11.3\%), Hispanic (2.9\%), Asian (1.9\%), and Native American (0.8\%) [30]. Most Auburn University freshmen had permanent residences in Alabama (57\%), but about $43 \%$ had permanent residences elsewhere such as Georgia (18.3\%), Florida (6.1\%), Tennessee (3.8\%), and Texas $(2.7 \%)$ to name a few [30].

Freshman volunteers were excluded from participation if they were under 17 years or older than 19 years of age, pregnant, married, had children, reported a diagnosed eating disorder, or enrolled at the university prior to fall semester 2007. An informed consent from participants and from parents for subjects under 19 years was obtained prior to study participation. This study was approved by the university's Institutional Review Board for the Use of Human Subject in Research.

2.1. Anthropometric and Body Composition Measurements. Participants were assessed at the beginning (about the first four weeks) of fall semester/end of summer (2007, 2008, 2009, and 2010) in late August and early September, at the end (about the last three weeks) of fall semester (2007 and 2008) in late November and early December, and at the end of spring semester $(2008,2009$, and 2010) in late April and early May. At the initial assessment, participants completed a demographic questionnaire providing selfreported information regarding sex, race/ethnicity, birth date, state of permanent residence, and residence location at college (e.g., on campus residence hall/dorm, off campus apartment, trailer, duplex, house, fraternity/sorority house, or at home with parents). At each assessment, body weight and composition were measured and participants completed questionnaires regarding environmental, behavioral, and lifestyle habits as well as body image and satisfaction, eating behavior regulation, stress, and depression. Height and body shape were measured at the beginning of fall and at the end of spring assessments each year. Participants received monetary compensation for study participation.

Body weight and height were measured with a digital scale and an attached height rod (Healthometer, Pelstar, LLC, Model 500KL, Bridgeview, IL); body composition was measured using bioelectrical impedance analysis (BodyStat, BioVant Systems, Detroit, MI), and body shape was assessed [providing waist circumference data] using the NX16 threedimensional body scanner ([TC $]^{2}$, Cary, NC) as described by Gropper and coworkers [9]. BMI was calculated for each participant by the standard formula, dividing weight by height squared $\left(\mathrm{kg} / \mathrm{m}^{2}\right)$; BMI calculations were done with each assessment to account for changes in weight and, for some individuals, in height. Participants were classified based on BMI as underweight, normal weight, overweight, or obese using Centers for Disease Control and Prevention definitions [31]. The adult BMI criteria for classification, instead of the BMI-for-age growth curves that end at age 20 years, were used since the college students were being followed longitudinally.

2.2. Statistical Analyses. Statistical analyses were performed using Instat 3.0 (GraphPad Software, San Diego, CA), and SPSS Statistics 17.0 (SPSS Inc., Chicago, IL). Differences in ethnicity/race between the university freshman population and the study population were examined using the chisquare test. Repeated measures analysis of variance (ANOVA) followed by Tukey's test was used to examine changes in outcome measures among the freshman, sophomore, and junior years. Changes were calculated for each year by subtracting outcome measures collected at the end of the spring semester from outcome measures collected at the beginning of the previous fall semester. Repeated measures ANOVA was also used to examine differences in outcome measures at the beginning of the freshman year versus the end of the junior year. A student's $t$-test was used to compare the weight and BMI of those who returned versus those who did not return for re-assessments as well as to compare differences in outcome measures between males and females. A $P$-value of $<0.05$ was considered statistically significant. Data are reported as mean \pm standard deviation unless noted differently.

\section{Results}

Of the 240 initial volunteers ( 155 or $65 \%$ females, 85 or $35 \%$ males), 114 participants ( 77 or $68 \%$ females, 37 or $32 \%$ males) returned for all assessments, and 149 participants, $62 \%$ (98 females, 51 males), returned for the end of junior year assessment. Of the 91 nonreturners, 24 (10\%) participants ( 7 males, 17 females) were found to be no longer enrolled at the university and three females (1.2\%) were not invited back to participate because of reported eating disorders. The 149 participants returning at the end of the junior year had similar demographics, that is, $81.9 \%$ Caucasian, 11.4\% African American, 2.7\% Hispanic, 2\% Asian, and $2 \%$ other, as the initial sample population, which was $81.7 \%$ Caucasian, $12.1 \%$ African American, $2.9 \%$ Hispanic, $1.7 \%$ Asian, and $1.7 \%$ other. In addition, the initial weight and BMI of those who returned $(65.0 \pm$ $14.7 \mathrm{~kg}[143.1 \pm 32.4 \mathrm{lbs}]$ and $22.6 \pm 4.2 \mathrm{~kg} / \mathrm{m}^{2}$, resp.) did not significantly differ from those of the nonreturners (66.3 $\pm 14.4 \mathrm{~kg}[145.8 \pm 31.8 \mathrm{lbs}]$ and $23.1 \pm 4.2 \mathrm{~kg} / \mathrm{m}^{2}$, resp.). Of the 149 participants assessed at the end of the junior year, $6.1 \%$ lived on campus, $89.2 \%$ lived off campus, $1.3 \%$ lived 
TABLE 1: Freshman, sophomore, and junior year changes in weight, body mass index, and body composition.*

\begin{tabular}{|c|c|c|c|}
\hline & Freshman year changes & Sophomore year changes & Junior year changes \\
\hline \multicolumn{4}{|l|}{ Weight (kg) } \\
\hline All & $1.2 \pm 3.1^{\mathrm{a}}$ & $0.5 \pm 2.9^{\mathrm{a}}$ & $0.6 \pm 3.8^{\mathrm{a}}$ \\
\hline Females & $0.9 \pm 3.1^{\mathrm{a}}$ & $0.1 \pm 2.6^{\mathrm{a}}$ & $0.0 \pm 3.9^{\mathrm{a}}$ \\
\hline Males & $1.8 \pm 3.0^{\mathrm{a}}$ & $1.2 \pm 3.4^{\mathrm{a}}$ & $1.9 \pm 3.2^{\mathrm{a}}$ \\
\hline \multicolumn{4}{|c|}{ Body mass index $\left(\mathrm{kg} / \mathrm{m}^{2}\right)$} \\
\hline All & $0.4 \pm 1.1^{\mathrm{a}}$ & $0.1 \pm 1.0^{\mathrm{a}}$ & $0.2 \pm 1.3^{\mathrm{a}}$ \\
\hline Females & $0.3 \pm 1.1^{\mathrm{a}}$ & $0.0 \pm 1.0^{\mathrm{a}}$ & $0.0 \pm 1.4^{\mathrm{a}}$ \\
\hline Males & $0.5 \pm 1.0^{\mathrm{a}}$ & $0.4 \pm 1.1^{\mathrm{a}}$ & $0.6 \pm 1.0^{\mathrm{a}}$ \\
\hline \multicolumn{4}{|c|}{ Body fat (percentage) } \\
\hline All & $1.6 \pm 2.5^{\mathrm{a}}$ & $-0.1 \pm 2.5^{\mathrm{b}}$ & $0.8 \pm 2.9^{\mathrm{a}, \mathrm{c}}$ \\
\hline Females & $1.3 \pm 2.7^{\mathrm{a}}$ & $-0.3 \pm 2.0^{\mathrm{b}}$ & $0.5 \pm 3.2^{\mathrm{a}, \mathrm{b}}$ \\
\hline Males & $2.2 \pm 1.9^{\mathrm{a}}$ & $0.5 \pm 3.3^{b}$ & $1.4 \pm 2.3^{\mathrm{a}, \mathrm{b}}$ \\
\hline \multicolumn{4}{|c|}{ Fat free mass (kg) } \\
\hline All & $-0.2 \pm 2.1^{\mathrm{a}}$ & $0.4 \pm 1.7^{\mathrm{a}}$ & $-0.2 \pm 2.0^{\mathrm{a}}$ \\
\hline Females & $-0.2 \pm 2.1^{\mathrm{a}, \mathrm{b}}$ & $0.3 \pm 1.5^{\mathrm{a}}$ & $-0.4 \pm 1.8^{\mathrm{b}}$ \\
\hline Males & $-0.1 \pm 2.2^{\mathrm{a}}$ & $0.7 \pm 2.1^{\mathrm{a}}$ & $0.3 \pm 2.5^{\mathrm{a}}$ \\
\hline \multicolumn{4}{|c|}{ Fat mass (kg) } \\
\hline All & $1.4 \pm 2.2^{\mathrm{a}}$ & $0.0 \pm 2.5^{\mathrm{b}}$ & $0.7 \pm 3.0^{\mathrm{a}, \mathrm{b}}$ \\
\hline Females & $1.1 \pm 2.3^{\mathrm{a}}$ & $-0.2 \pm 1.9^{\mathrm{b}}$ & $0.3 \pm 3.3^{\mathrm{a}, \mathrm{b}}$ \\
\hline Males & $2.0 \pm 2.0^{\mathrm{a}}$ & $0.6 \pm 3.4^{\mathrm{a}}$ & $1.5 \pm 2.3^{\mathrm{a}}$ \\
\hline \multicolumn{4}{|l|}{ Waist $(\mathrm{cm})$} \\
\hline All & $-0.53 \pm 3.12^{\mathrm{a}}$ & $0.46 \pm 2.54^{\mathrm{a}}$ & $0.20 \pm 3.35^{\mathrm{a}}$ \\
\hline Females & $-0.30 \pm 2.46^{\mathrm{a}}$ & $0.15 \pm 2.29^{\mathrm{a}}$ & $0.05 \pm 2.77^{\mathrm{a}}$ \\
\hline Males & $-1.04 \pm 4.27^{\mathrm{a}}$ & $1.17 \pm 2.87^{\mathrm{a}}$ & $0.76 \pm 4.42^{\mathrm{a}}$ \\
\hline
\end{tabular}

${ }^{*} n=37$ males and $n=77$ females.

a,b,c Values in rows with different letters are significantly different $P<0.05$.

at home, and $3.4 \%$ lived in a fraternity house. Additional information regarding this sample population is described by Gropper and coworkers [10].

3.1. Yearly Anthropometric Changes. Changes in body weight, BMI, percent body fat, fat-free mass, fat mass, and waist circumference during the freshman, sophomore, and junior years are shown in Table 1. Gains in percent body fat were significantly greater during the freshman year than the sophomore year, and significantly greater during the junior year than the sophomore year. Losses in fat-free mass occurred during both the freshman and junior years in the females; changes in fat-free mass were significantly greater during the junior year than the sophomore year in females. A trend $(P=0.096)$ was observed toward a significant difference among changes in waist circumference for all subjects.

3.2. Three-Year Anthropometric Changes. Table 2 provides information on body weight and composition changes over the three-year period for the 149 participants who were present for assessments at the beginning of the freshman year and the end of the junior year. Weight gain averaged $2.1 \mathrm{~kg}$ (4.6 lbs), range -11.7 to $21.3 \mathrm{~kg}$ ( -25.8 to $46.8 \mathrm{lbs}$ ). Significant gains in BMI $\left(0.7 \mathrm{~kg} / \mathrm{m}^{2}\right)$, percent body fat
(2.7\%), and fat mass $(2.3 \mathrm{~kg}[5.0 \mathrm{lbs}])$ were also observed over the first three years of college. A significant loss of fatfree mass $(-0.5 \mathrm{~kg}[-1.1 \mathrm{lbs}])$ was found among females. Waist circumference did not significantly change over the three-year period, and the percentages of males and females with waist circumference measurements greater than or equal to $102 \mathrm{~cm}\left(40^{\prime \prime}\right)$ and $88 \mathrm{~cm}\left(35^{\prime \prime}\right)$, respectively, did not significantly increase. Males gained significantly more weight $(P=0.005)$, BMI $(P=0.022)$, percent body fat $(P=0.001)$, and absolute fat mass $(P=0.006)$, but not fat-free mass or waist circumference than the females over the three-year period.

Over two-thirds (43 males, 61 females) (70\%) of the 149 participants gained weight; weight gain over the three years among those in this weight gain group was $4.3 \pm 3.7 \mathrm{~kg}$ $(9.4 \pm 8.2 \mathrm{lbs})$ and did not significantly differ between males and females. Additionally, in this weight gain group, there were gains of $1.4 \pm 1.2 \mathrm{~kg} / \mathrm{m}^{2} \mathrm{BMI}, 0.7 \pm 2 \mathrm{~kg}(1.5 \pm 4.4 \mathrm{lbs})$ fat-free mass, $3.5 \pm 3 \mathrm{~kg}(7.8 \pm 6.6 \mathrm{lbs})$ fat mass, and 4.0 $\pm 3.1 \%$ body fat. Eleven participants $(7 \%)$ gained $\geq 9.1 \mathrm{~kg}$ (20 lbs); 28 participants (19\%) gained 4.5 to $9.0 \mathrm{~kg}$ (10 to $19.9 \mathrm{lbs}) ; 27$ participants (18\%) gained 2.3 to $4.4 \mathrm{~kg}$ (5.0 to $9.9 \mathrm{lbs}$ ), and 38 participants $(26 \%)$ gained $<2.3 \mathrm{~kg}$ ( $5 \mathrm{lbs}$ ). About $30 \%(n=45)$ of participants lost weight with 23 (15\%) losing <2.3 kg (5lbs), 10 (7\%) losing 2.3 to $4.4 \mathrm{~kg}(5$ to $9.9 \mathrm{lbs}$ ), and 10 (7\%) losing 4.5 to $9.1 \mathrm{~kg}$ (10 to $20 \mathrm{lbs}$ ). 
TABLE 2: Weight, body mass index, and body composition changes between the college freshman and junior years. ${ }^{a}$

\begin{tabular}{|c|c|c|c|}
\hline & Beginning of freshman year & End of junior year & Change \\
\hline \multicolumn{4}{|l|}{ Weight (kg) } \\
\hline All & $65.0 \pm 14.7$ & $67.1 \pm 16.2$ & $2.1 \pm 4.8^{\mathrm{b}}$ \\
\hline Females & $59.8 \pm 12.1$ & $61.1 \pm 13.7$ & $1.3 \pm 4.5^{b}$ \\
\hline Males & $75.1 \pm 14.0$ & $78.7 \pm 14.4$ & $3.6 \pm 4.8^{\mathrm{b}}$ \\
\hline \multicolumn{4}{|c|}{ Body mass index $\left(\mathrm{kg} / \mathrm{m}^{2}\right)$} \\
\hline All & $22.6 \pm 4.2$ & $23.3 \pm 4.7$ & $0.7 \pm 1.6^{\mathrm{b}}$ \\
\hline Females & $22.1 \pm 4.0$ & $22.5 \pm 4.5$ & $0.5 \pm 1.6^{\mathrm{b}}$ \\
\hline Males & $23.7 \pm 4.6$ & $24.8 \pm 4.5$ & $1.1 \pm 1.4^{\mathrm{b}}$ \\
\hline \multicolumn{4}{|c|}{ Body fat (percentage) } \\
\hline All & $18.3 \pm 7.5$ & $21.0 \pm 7.4$ & $2.7 \pm 3.3^{\mathrm{b}}$ \\
\hline Females & $22.0 \pm 5.3$ & $24.2 \pm 5.7$ & $2.2 \pm 3.3^{b}$ \\
\hline Males & $11.0 \pm 5.6$ & $14.7 \pm 6.0$ & $3.7 \pm 2.9^{b}$ \\
\hline \multicolumn{4}{|c|}{ Fat free mass (kg) } \\
\hline All & $52.8 \pm 11.6$ & $52.5 \pm 11.8$ & $0.3 \pm 2.6$ \\
\hline Females & $46.1 \pm 6.0$ & $45.6 \pm 5.9$ & $-0.5 \pm 2.2^{\mathrm{b}}$ \\
\hline Males & $66.2 \pm 7.9$ & $66.3 \pm 7.8$ & $0.1 \pm 3.2$ \\
\hline \multicolumn{4}{|c|}{ Fat mass (kg) } \\
\hline All & $12.0 \pm 8.1$ & $14.3 \pm 9.1$ & $2.3 \pm 3.5^{b}$ \\
\hline Females & $13.6 \pm 7.5$ & $15.4 \pm 9.1$ & $1.8 \pm 3.5^{\mathrm{b}}$ \\
\hline Males & $8.9 \pm 8.6$ & $12.2 \pm 9.0$ & $-3.3 \pm 3.0^{\mathrm{b}}$ \\
\hline \multicolumn{4}{|l|}{ Waist $(\mathrm{cm})$} \\
\hline All & $74.60 \pm 8.81$ & $74.88 \pm 9.37$ & $0.28 \pm 3.25$ \\
\hline Females & $71.22 \pm 6.68$ & $71.27 \pm 6.68$ & $0.05 \pm 2.77$ \\
\hline Males & $81.69 \pm 8.59$ & $82.45 \pm 9.73$ & $0.76 \pm 4.06$ \\
\hline
\end{tabular}

${ }^{a} n=51$ males, $n=98$ females.

${ }^{b}$ Statistically significant $(<0.05)$ change from freshman year.

The initial BMI of the participants was $22.6 \pm 4.2 \mathrm{~kg} / \mathrm{m}^{2}$, range 15.2 to $50.7 \mathrm{~kg} / \mathrm{m}^{2}$, and by the end of the junior year, BMI had significantly increased, averaging $23.3 \pm 4.7 \mathrm{~kg} / \mathrm{m}^{2}$, with a range of 16.7 to $57.8 \mathrm{~kg} / \mathrm{m}^{2}$. At the beginning of the freshman year, the percentages of participants classified as underweight, normal weight, and overweight/obese were $5 \%, 79 \%$, and $15 \%$, respectively, whereas by the end of the junior year these percentages were $5 \%, 70 \%$, and $24 \%$, respectively. Initially five females had $\geq 30 \%$ body fat, yet by the end of the junior year 10 females had $\geq 30 \%$ body fat; similarly, initially one male had $\geq 20 \%$ body fat, and by the end of the junior year five males had $\geq 20 \%$ body fat.

\section{Discussion}

This study is the first to longitudinally follow students through college tracking changes in body weight, composition, and shape. While the first (freshman) year of college was associated with the greatest gains in weight and body fat, the third (junior) year of college was also associated with absolute gains in weight, BMI, and fat mass, and significant gains in body fat percentage. These unhealthy gains in percent body fat during the junior year were about half of what was observed during the freshman year and counter the improvements (minimal gains or loss of body fat) observed during the sophomore year. Similar trends were observed with gains in fat mass. Yet, perhaps more troubling, fat-free mass loss among females, which was observed during the freshman year, was greatest during the junior year.

Three-year weight changes were modest, yet highly variable, with absolute weight gain ranging from $-11.7 \mathrm{~kg}$ to $21.3 \mathrm{~kg}$ ( -25.8 to $46.8 \mathrm{lbs}$ ), and averaging $2.1 \mathrm{~kg}$ ( $4.6 \mathrm{lbs}$ ) for the whole group (females: $1.3 \mathrm{~kg}$ [2.9 lbs], males: $3.6 \mathrm{~kg}$ [7.9 lbs]), and $4.3 \mathrm{~kg}(9.4 \mathrm{lbs})$ among the weight gain group. These findings are fairly consistent with the results of Racette and coworkers [32] who documented a $5.5 \mathrm{lb}(2.5 \mathrm{~kg})$ weight gain (females $3.75 \mathrm{lbs}(1.7 \mathrm{~kg})$, males $9.26 \mathrm{lbs}(4.2 \mathrm{~kg})$, and $0.7 \mathrm{~kg} / \mathrm{m}^{2}$ BMI gain (females $0.5 \mathrm{~kg} / \mathrm{m}^{2}$, males $1.1 \mathrm{~kg} / \mathrm{m}^{2}$ ) (but did not examine body composition)) over a four-year period in a group of 204 college students. These four-year BMI gains reported by Racette and coworkers [32] mirrored the three-year gains of $0.7 \mathrm{~kg} / \mathrm{m}^{2}$ (females $0.5 \mathrm{~kg} / \mathrm{m}^{2}$, males $1.1 \mathrm{~kg} / \mathrm{m}^{2}$ ) found in the present study. BMI gains in this study were also consistent with expected gains between the ages of 18 and 20 years (derived from the Centers for Disease Control and Prevention BMI for age growth curves) of $0.5 \mathrm{~kg} / \mathrm{m}^{2}$ for females and of $1.2 \mathrm{~kg} / \mathrm{m}^{2}$ for males [31]. Unfortunately, when examining the composition of the weight gain in the present study, the $0.5 \mathrm{~kg}(1.1 \mathrm{lb})$ loss of fatfree mass among the females and the $0.04 \mathrm{~kg}(0.1 \mathrm{lb})$ gain of fat-free mass among the males were surpassed by fat mass 
gains of $1.7 \mathrm{~kg}(3.8 \mathrm{lbs})$ in females and $3.4 \mathrm{~kg}(7.5 \mathrm{lbs})$ in males.

Between the start of college and the end of the junior year, the decreased percentage of students classified as normal weight (from $79 \%$ to $70 \%$ ) and the increased percentage classified as overweight/obese (15\% to $24 \%$ ) was worrisome, but not unexpected. While other studies have not tracked changes into the junior year, this rise in the number of students classified as overweight/obese has also been reported by Lloyd-Richardson and colleagues [26] who showed that the percentages of students classified as overweight/obese rose from $20.3 \%$ initially to $35.1 \%$ by end of sophomore year. The use of BMI, however, does not enable differentiation between fat-free mass and fat mass. Gains in body fat have been associated with increased health risks including obesity comorbidities such as heart disease as well as all-cause mortality and cardiovascular mortality [33-35]. For example, a study of 6,171 individuals (aged 20 years and older) with normal weight obesity (i.e., a BMI in the range of 18.5 to $24.9 \mathrm{~kg} / \mathrm{m}^{2}$ but a body fat percentage greater than $23.1 \%$ in males and greater than $33.3 \%$ in females) found a higher prevalence of both dyslipidemia and hypertension among males and cardiovascular disease among females [33]. In the present three-year study period, the number of females with $\geq 30 \%$ body fat doubled and the number of males with $\geq 20 \%$ body fat increased fivefold. Should such trends continue these very young adults may find themselves at increased disease risk.

The results of this study provide important new findings about changes in body weight and especially body composition during the first three years of college. Participants of this study, however, attended a public university. Thus, the results may differ for individuals attending private universities or not attending a university, although nonstudents (aged 18 to 24 years) have been found to be more often overweight than students [36]. Additionally, while a loss of subjects at followup occurred, an analysis of the initial data from the noncompleters showed that they did not significantly differ in weight or BMI from those who completed the study.

\section{Conclusions}

These small yearly gains in weight and fat mass, especially if continued into the senior year of college and during the early adulthood years, may be contributing to the high prevalence of obesity in the young adult population. Efforts on college campuses are needed to promote healthy lifestyles among its student population throughout each of the college years.

\section{Conflict of Interests}

The authors declared no conflict of interests.

\section{Acknowledgments}

This research was supported by Alabama Agricultural Experiment Station projects 013-020 and 07-020, and an AAES
Initiative Grant. A special thanks to M. J. Gropper for his statistical assistance.

\section{References}

[1] Centers for Disease Control and Prevention, Overweight and obesity, 2010, http://www.cdc.gov/obesity/data/trends.html.

[2] Centers for Disease Control and Prevention, Behavioral Risk Factor Surveillance System: Prevalence and Trends data, 2010, http://apps.nccd.cdc.gov/brfss/list.asp?cat=OB\&yr=2010\& qkey $=4409 \&$ state $=$ All.

[3] A. H. Mokdad, M. K. Serdula, W. H. Dietz, B. A. Bowman, J. S. Marks, and J. P. Koplan, "The spread of the obesity epidemic in the United States, 1991-1998," Journal of the American Medical Association, vol. 282, no. 16, pp. 1519-1522, 1999.

[4] D. A. Anderson, J. R. Shapiro, and J. D. Lundgren, "The freshman year of college as a critical period for weight gain: an initial evaluation," Eating Behaviors, vol. 4, no. 4, pp. 363367, 2003.

[5] S. M. Butler, D. R. Black, C. L. Blue, and R. J. Gretebeck, "Change in diet, physical activity, and body weight in female college freshman," American Journal of Health Behavior, vol. 28, no. 1, pp. 24-32, 2004.

[6] C. D. Economos, M. L. Hildebrandt, and R. R. Hyatt, "College freshman stress and weight change: differences by gender," American Journal of Health Behavior, vol. 32, no. 1, pp. 16-25, 2008.

[7] M. J. Edmonds, K. J. Ferreira, E. A. Nikiforuk et al., "Body weight and percent body fat increase during the transition from high school to university in females," Journal of the American Dietetic Association, vol. 108, no. 6, pp. 1033-1037, 2008.

[8] M. A. Graham and A. L. Jones, "Freshman 15: valid theory or harmful myth?" Journal of American College Health, vol. 50, no. 4, pp. 171-173, 2002.

[9] S. S. Gropper, K. P. Simmons, A. Gaines et al., "The freshman 15-a closer look," Journal of American College Health, vol. 58, no. 3, pp. 223-231, 2009.

[10] S. S. Gropper, A. Newton, P. Harrington, K. P. Simmons, L. J. Connell, and P. Ulrich, "Body composition changes during the first two years of university," Preventive Medicine, vol. 52, no. 1, pp. 20-22, 2011.

[11] L. Hajhosseini, T. Holmes, P. Mohamadi, V. Goudarzi, L. McProud, and C. B. Hollenbeck, "Changes in body weight, body composition and resting metabolic rate (RMR) in firstyear university freshmen students," Journal of the American College of Nutrition, vol. 25, no. 2, pp. 123-127, 2006.

[12] C. N. Hodge, L. A. Jackson, and L. Sullivan, "The "freshman 15 " facts and fantasies about weight gain in college women," Psychology Women Quarterly, vol. 17, no. 1, pp. 119-126, 1993.

[13] D. J. Hoffman, P. Policastro, V. Quick, and S.-K. Lee, "Changes in body weight and fat mass of men and women in the first year of college: a study of the 'freshman 15,' Journal of American College Health, vol. 55, no. 1, pp. 41-46, 2006.

[14] J. M. Holm-Denoma, T. E. Joiner, K. D. Vohs, and T. F, Heatherton, "The "freshman fifteen" (the "freshman five" actually): predictors and possible explanations," Health Psychology, vol. 27, supplement 1, pp. S3-S9, 2008.

[15] M. F. Hovell, C. R. Mewborn, Y. Randle, and S. FowlerJohnson, "Risk of excess weight gain in university women: a three-year community controlled analysis," Addictive Behaviors, vol. 10, no. 1, pp. 15-28, 1985. 
[16] M. E. Jung, S. R. Bray, and K. A. M. Ginis, "Behavior change and the freshman 15: tracking physical activity and dietary patterns in 1st-year university women," Journal of American College Health, vol. 56, no. 5, pp. 523-530, 2008.

[17] D. G. Kasparek, S. J. Corwin, R. F. Valois, R. G. Sargent, and R. L. Morris, "Selected health behaviors that influence college freshman weight change," Journal of American College Health, vol. 56, no. 4, pp. 437-444, 2008.

[18] D. A. Levitsky, C. A. Halbmaier, and G. Mrdjenovic, "The freshman weight gain: a model for the study of the epidemic of obesity," International Journal of Obesity, vol. 28, no. 11, pp. 1435-1442, 2004.

[19] E. E. Lloyd-Richardson, M. L. Lucero, J. R. DiBello, A. E. Jacobson, and R. R. Wing, "The relationship between alcohol use, eating habits and weight change in college freshmen," Eating Behaviors, vol. 9, no. 4, pp. 504-508, 2008.

[20] M. R. Lowe, R. A. Annunziato, J. T. Markowitz et al., "Multiple types of dieting prospectively predict weight gain during the freshman year of college," Appetite, vol. 47, no. 1, pp. 83-90, 2006.

[21] G. Mifsud, K. Duval, and E. Doucet, "Low body fat and high cardiorespiratory fitness at the onset of the freshmen year may not protect against weight gain," British Journal of Nutrition, vol. 101, no. 9, pp. 1406-1412, 2009.

[22] M. L. Morrow, K. C. Heesch, M. K. Dinger, H. R. Hull, A. W. Kneehans, and D. A. Fields, "Freshman 15: fact or fiction?" Obesity, vol. 14, no. 8, pp. 1438-1443, 2006.

[23] V. Provencher, J. Polivy, M. G. Wintre et al., "Who gains or who loses weight? Psychosocial factors among first-year university students," Physiology and Behavior, vol. 96, no. 1, pp. 135-141, 2009.

[24] A. W. Pullman, R. C. Masters, L. C. Zalot et al., "Effect of the transition from high school to university on anthropometric and lifestyle variables in males," Applied Physiology, Nutrition and Metabolism, vol. 34, no. 2, pp. 162-171, 2009.

[25] H. J. Wengreen and C. Moncur, "Change in diet, physical activity, and body weight among young-adults during the transition from high school to college," Nutrition Journal, vol. 8, no. 1, article 32, pp. 32-39, 2009.

[26] E. E. Lloyd-Richardson, S. Bailey, J. L. Fava, and R. Wing, "A prospective study of weight gain during the college freshman and sophomore years," Preventive Medicine, vol. 48, no. 3, pp. 256-261, 2009.

[27] S. B. Racette, S. S. Deusinger, M. J. Strube, G. R. Highstein, and R. H. Deusinger, "Weight changes, exercise, and dietary patterns during freshman and sophomore years of college," Journal of American College Health, vol. 53, no. 6, pp. 245-251, 2005.

[28] H. R. Hull, M. L. Morrow, M. K. Dinger, J. L. Han, and D. A. Fields, "Characterization of body weight and composition changes during the sophomore year of college," BMC Women's Health, vol. 7, no. 1, article 21, pp. 21-27, 2007.

[29] U. S. Surgeon General, Surgeon General's vision for a healthy and fit nation, 2010, http://www.surgeongeneral.gov/library/ obesityvision/obesityvision2010.pdf.

[30] Auburn University, Auburn University Office of Institutional Research and Assessment, 2007, https://oira.auburn.edu/.

[31] Centers for Disease Control and Prevention, Overweight and obesity, 2010, http://www.cdc.gov/obesity/defining.html.

[32] S. B. Racette, S. S. Deusinger, M. J. Strube, G. R. Highstein, and R. H. Deusinger, "Changes in weight and health behaviors from freshman through senior year of college," Journal of Nutrition Education and Behavior, vol. 40, no. 1, pp. 39-42, 2008.
[33] A. Romero-Corral, V. K. Somers, J. Sierra-Johnson et al., "Normal weight obesity: a risk factor for cardiometabolic dysregulation and cardiovascular mortality," European Heart Journal, vol. 31, no. 6, pp. 737-746, 2010.

[34] N. Dervaux, M. Wubuli, J. L. Megnien, G. Chironi, and A. Simon, "Comparative associations of adiposity measures with cardiometabolic risk burden in asymptomatic subjects," Atherosclerosis, vol. 201, no. 2, pp. 413-417, 2008.

[35] J. Gómez-Ambrosi, C. Silva, J. C. Galofré et al., "Body adiposity and type 2 diabetes: increased risk with a high body fat percentage even having a normal BMI," Obesity, vol. 19, no. 7, pp. 1439-1444, 2011.

[36] C. C. Georgiou, N. M. Betts, S. L. Hoerr et al., "Among young adults, college students and graduates practiced more healthful habits and made more healthful food choices than did nonstudents," Journal of the American Dietetic Association, vol. 97, no. 7, pp. 754-759, 1997. 


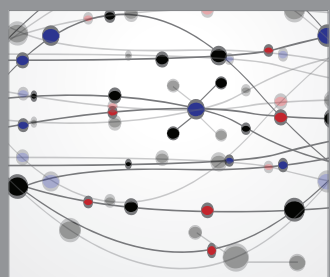

The Scientific World Journal
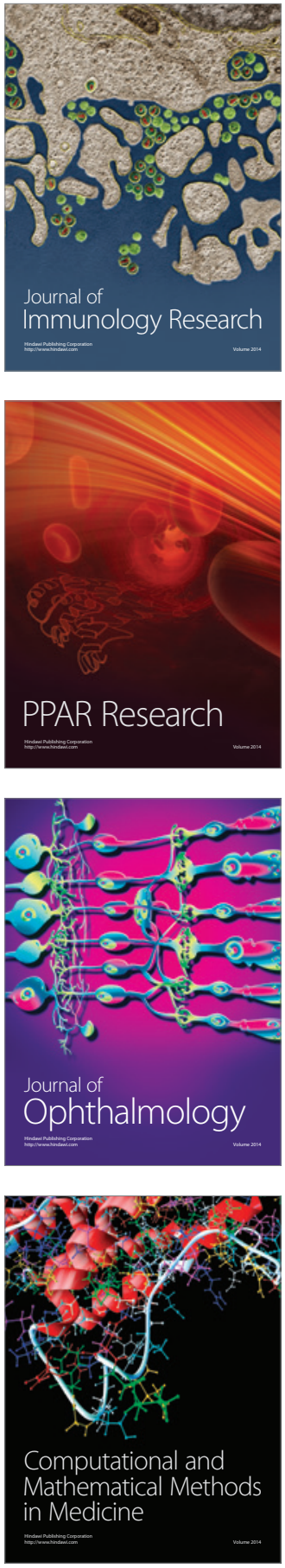

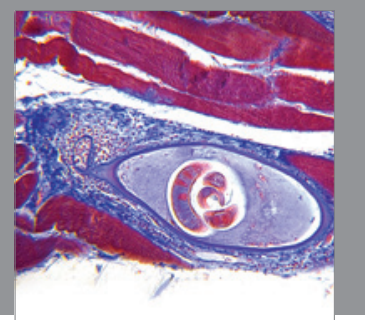

Gastroenterology

Research and Practice
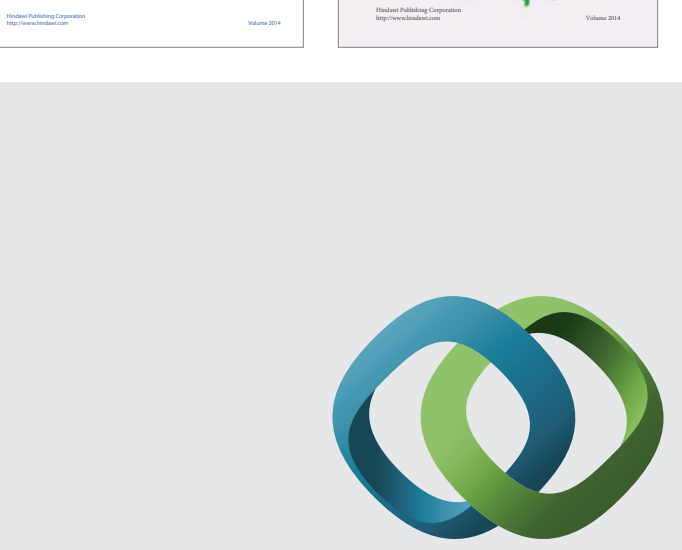

\section{Hindawi}

Submit your manuscripts at

http://www.hindawi.com
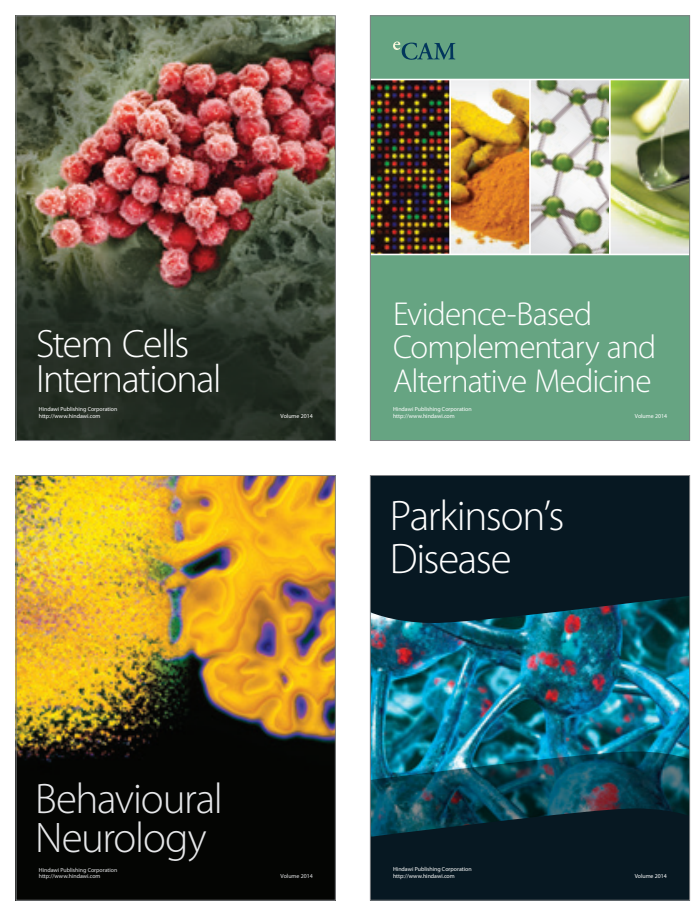

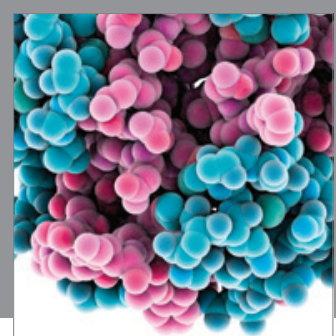

Journal of
Diabetes Research

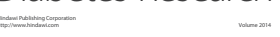

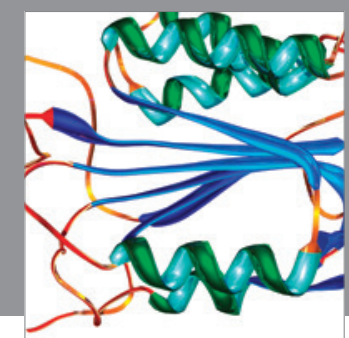

Disease Markers
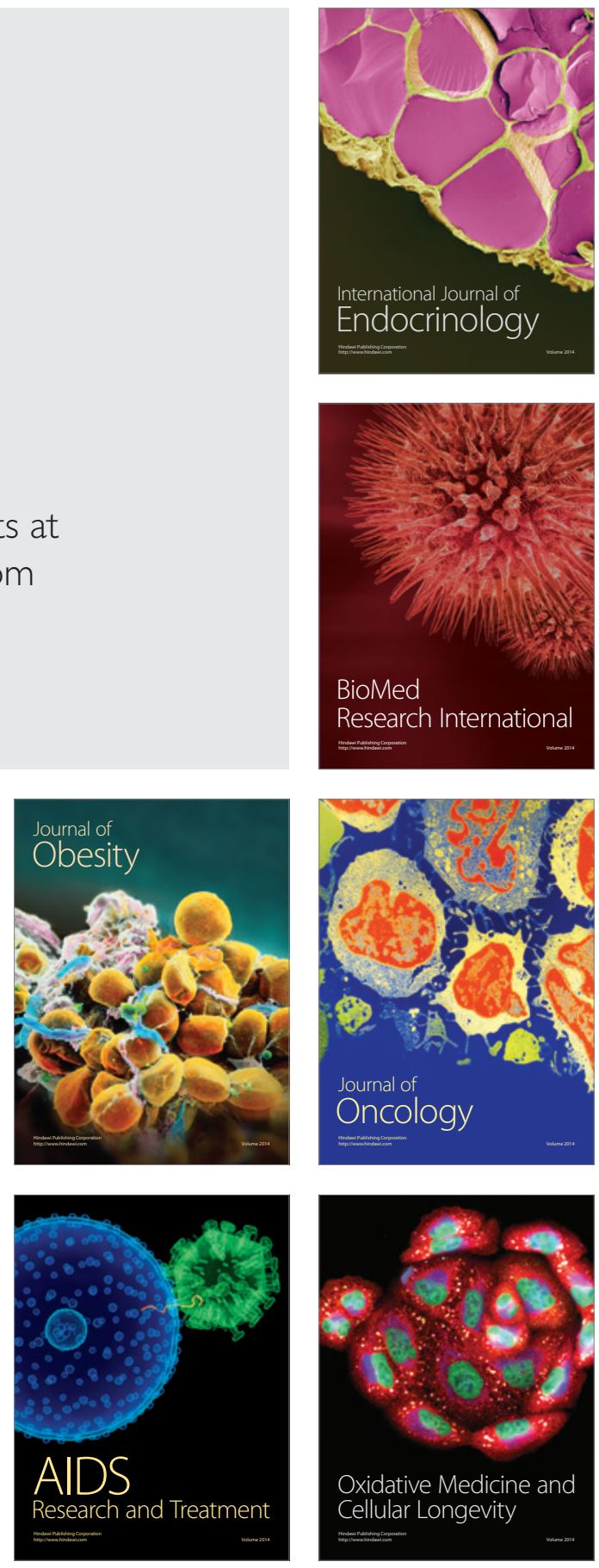